\title{
CROSS-CULTURAL DIFFERENCES BETWEEN AMERICANS AND UKRAINIANS
}

\author{
Elina Koliada \\ Lesya Ukrainka Volyn National University, \\ Lutsk, Ukraine \\ elina.koliada@vnu.edu.ua \\ Iryna Kalynovska \\ Lesya Ukrainka Volyn National University, \\ Lutsk, Ukraine \\ kalynovska@vnu.edu.ua
}

Received March, 22, 2020; Accepted May, 11, 2020

\begin{abstract}
This article considers cross-cultural communication between Americans and Ukrainians. Its purpose is to stress how Americans and Ukrainians think and express their thoughts, how they act interpersonally, and how they follow the many hidden rules that govern conduct. In today's world, it is both valuable and necessary to be aware of intercultural differences. Cross-cultural communication refers to the communication between people who have different cultural backgrounds. Misunderstandings and problems between them primarily occur because they assume that what is natural, appropriate, and acceptable for them must be natural, appropriate, and acceptable to others. Different cultural assumptions may underlie different views on what is "polite" or "rude." The authors draw attention to the most apparent and fundamental areas of cultural understanding breakdowns, which exist at the everyday level of life between native speakers of American English and Ukrainian. They point out that it is not enough to learn the language's vocabulary and grammar to understand and be understood by native speakers. The mentality and world view of native speakers is crucial in choosing to use a particular word and the cultural context. The article covers the most basic discourse areas where breakdowns often occur in intercultural communication. They are: addressing people, meeting someone new, meeting and parting etiquette, and receiving guests.
\end{abstract} Ukrainian.

Keywords: cross-cultural communication, language, culture, etiquette, American English,

\section{Introduction}

Cross-cultural issues have become an essential and popular topic in recent years that have interested sociologists, anthropologists, psychologists, and linguists. Nothing is more challenging for a foreigner to grasp than the unspoken and unwritten rules of etiquette and behavior in a foreign culture. Our personal experience has shown that it is not enough to learn the language's vocabulary and grammar to understand and be understood by native speakers. Traditional teaching methods gave a broad base of vocabulary and grammar but failed to introduce the mentality and worldview of native speakers. There are many textbooks written to train Ukrainian students of English in British English, and there are fewer ones in 
American English. Because of differing world views, the American and British culture and language differ significantly on many levels. However, the non-native speaker of English will often assume the similarities rather than the differences between them. The American anthropologist Edward Hall commented that "no two languages are alike /... Some are so dissimilar /.../ that they force the speaker into two different versions of reality" (Hall, 1981: 101). The nature of a language and its speakers' shared assumptions mold their views of their own group's culture and the outside world. The failure to observe the unwritten and subtle rules of accepted behavior in the US can seriously impact business and personal relations.

The first step in social interaction comes with addressing someone - i.e., what you call him or her. We will see basic questions that occur in becoming acquainted with a new person in the light of how they are understood in a broader sense by Americans in general. Then we will dwell upon meeting and parting etiquette and cultural differences in receiving guests.

\section{Addressing People}

In English-speaking countries, individuals are given three names: the first name, the middle/second name, and the last name. The first two names are the person's common names; however, they will only share the name they go by during the introduction. In this case, the first name or middle name may be used as the preferred name by the person. Asking for the person's second common name is rarely done and should not be done during introductions. If genuine interest lies in learning the person's full name, the most appropriate and polite way to present this question is to repeat the person's name and ask if that is the person's first name. The family name in American English is the last name instead of British English's surname.

At a first meeting, if an American addresses a Ukrainian as "Mr. Petrenko," the response should be, "Mr. Smith," and that should be the form of address until Smith either says, "Call me Jim" or calls his interlocutor "Ihor." If one is unsure of what to call someone, it is best to use a formal address or simply ask one of these questions: What should I call you? Can I call you [first name]?

When introducing oneself, Ukrainian names should not be "Americanized." If the name has an English cognate, it is acceptable to say, "I'm Pavlo - that's Paul, in English," or "I'm Petro, Peter in English." However, if the name is Ivan, going around saying "I'm John," sounds rather peculiar. Americans know that this is not a Ukrainian name and will wonder if the Ukrainian is "ashamed" of his name or pretends to be an American.

A complex concept for an American to fully grasp is the Ukrainians referring to each other by their given and patronymic names. There is no counterpart to the Slavic patronymic name in English-speaking countries, which is an essential part of any full Ukrainian name. Patronymics are personal names derived from one's father's name to distinguish one person from another. They emerged in the Kyivan Rus' period before they adopted surnames. The practice is still prevalent today. Patronymic name marks the respectful attitude to a person's age or status. A threepart personal name (one's patronymic name following one's first name and preceding one's surname) is an obligatory form of one's identification in such 
documents, as one's birth certificate, internal passport, and certificates of education. A full-name address is established as a norm in a professional and social hierarchy, most commonly with one's superior colleagues or officials. For courtesy reasons, it is also admitted for inferior and peer co-workers.

The most common mistake for an American when addressing a Ukrainian person is to assume that the patronymic name takes the place of the person's last name. Once reaching a level of intimacy, it is common for the American to drop the patronymic name in preference for using only the given name, since the use of both names shows a lack of familiarity to the person in the American mindset (Kovalskaya \& Ritchey, 2001: 10). Ukrainians need to be aware that in modern American society, even in work relations, it is not unusual for employees to refer to each other or their clients by only their first names. This illustration is taken from a textbook by Linda Cypres, "Let's Speak Business English!":

When Josef moved to North Carolina from Czechia, what shocked him the most was the use of his first name by total strangers. When his bank called him, the female employee would say: "Josef, this is Trisha at Central Bank". Or when he was waiting at the dentist's office, the receptionist would call out "Josef"? People he did not even know and had never met called him by his first name! In Czechia, as in many other European countries, one addresses people by their last name or title. Only when you know someone quite well, perhaps after some years, would you begin to use the first name. Using the first name would be too personal and considered impolite in his country. Josef learned that using first names in the United States is just a way of doing business, and is based on a culture in which people are considered equal, and where business customers are cultivated as friends" (Cypres, 2001: 216-217).

Thus, what is considered rude behavior in one culture may be welcomed as friendly or polite in another culture. In situations that are not strictly formal, North Americans tend to switch to first names, and they do so more readily than the British and much faster than Ukrainians.

If the situation is formal, it is appropriate to use "Mr." and the family name for men, and "Mrs." (the form of address for a married woman) or "Miss" (the form of address for an unmarried lady) and the family name for women. For example, "Mrs. Johnson, please see the manager." "Ms." often replaces "Mrs." and "Miss." One should not use "Mr.," "Mrs.," "Miss," or "Ms." with only a first name or by itself; the same is true for "Dr," "Professor," "Judge." For example, we can say Miss Brown or Miss Mary Brown, but not Miss Mary (Puffalt \& Starko, 2003: 41). Such forms of address as Mr. Jim or Miss Ellen, or Mrs. Jane were used by 19th-century slaves and servants when speaking to their masters. Nowadays this form of address can only be used when speaking to a member of the clergy: Father Thomas or Sister Maria (Visson, 2013: 58).

We note that the words "Dr," "Professor," "Judge," rather than "Mr.," "Ms.," "Mrs." are generally used in formal situations for addressing people who have these respective degrees or titles. In Ukrainian, it is possible to use a form such as "пане професоре." In contrast, in English, one needs to include the last name in the comparably respectful form, such as "Mr. Brown" (it is not possible to say, "Mr. Teacher").

We need to make a special mention concerning the address forms that do not include the person's name. The English greeting, "sir," is used when addressing a 
customer or a military superior. In addressing a stranger, a man can always use "Sir." In American English, one may use "sir" or "mister" to get the attention of a man whose name you do not know: "Sir! You dropped your wallet!", "Hey, mister, you dropped your paper." However, "sir" would be much more appropriate and is by far the most desirable alternative (Puffalt \& Starko, 2003: 42).

Addressing an unknown woman as "Miss" is always acceptable. For example, the most common form of address used with service personnel such as a waitress "Miss, I'd like a small orange juice, please, and whole wheat toast," or with a secretary, "Miss, I'd like to leave a message for Mr. Johnson." In addressing someone in the street, "Miss, you dropped your glove," would be appropriate. When speaking to an older woman, "Madam" or "Ma'am" is acceptable. It shows respect and indicates that the speaker, using this address, acknowledges the other interlocutor's superiority (Knodel, 2007: 9).

For other possibilities which do not include a surname, we may consider the following examples:

Miss, can I leave early? (addressing a female teacher)

Will he be all right, doctor? (speaking to a medical doctor; note that in the UK, male surgeons and dentists use "Mr." instead of "Dr")

Thank you, nurse. (addressing a nurse in a hospital)

Excuse me, officer. (addressing a police officer) (Puffalt \& Starko, 2003: 42).

In Ukraine, “пан/пані” and “добродій/добродійка" are convenient means of addressing people if one wishes to be polite and respectful. They may be used with a first name and/or a surname, a title or by themselves. For ехаmple, пане Іване; пані Ольго; пані (Софіє) Бурлако!; пане Пилипчуку!: добродію (Іване) Іваненко!; пані вчителько; пане депутате (Radevych-Vynnytskyi, 2006: 89-91).

It is appropriate to address a tiny child as "dear," "honey," or "sweetie," but these words should not be used when speaking to a woman - regardless of her age - unless she is a very close friend. As opposed to Ukrainian, words such as "boy," "girl," or "woman" are not used as forms of address. "Lady" is commonly used sarcastically to express a negative request or sentiment; an American watching a movie might snap at the talkative female in the row in front of him, "Lady, would you please be quiet!" (Visson, 2013:59).

\section{Meeting Someone New}

Nationality. Unlike in Ukrainian where there is a separate concept of nationality (національність) and citizenship (громадянство), in English, the words "nationality" and "citizenship" are synonymous. The Ukrainian concept of національність does not exist in American English. Therefore, an American who hears the question of their nationality will automatically share their citizenship (Kovalskaya \& Ritchey, 2001: 11). It will only further complicate the issue when a Ukrainian insists on knowing what the American's passport lists as their nationality since the American passport will only state that the person is an American citizen. Implying that "Jewish" is a nationality will be taken as an insult since, in the US, Jews are considered as a religion and not as a "nationality" (Visson, Lynn, 2013: 120). An American wondering about someone's background might ask, "Where are your parents/grandparents/folk from?" or "Where were they from originally?" This 
question is two-pronged, meaning both "Where (in the US or abroad) were your parents/grandparents born?" and "What is your ethnic background?" Someone whose parents or grandparents were born in Ukraine might say, "I'm of Ukrainian background/origin," or "My parents came from Ukraine." Alternatively, the answer might be "I was born here but my family's from Ukraine," or "We're UkrainianAmericans." Suppose a Ukrainian would like to know національність of the person. In that case, it is best to ask if they know their heritage by asking if the American knows where their family originated. It should be noted that the word "heritage", which is used in conversations about where the person's ancestors come from, is best translated into Ukrainian as "національне походження". A Ukrainian should not be surprised if either American answers that they do not know their heritage or answer with a list that could include even more than five countries from where their ancestors immigrated.

Place of Residence. One of the most commonly asked questions in Ukrainian is “Звідки ти/ви?" This phrase in English is "Where are you from?" or "Where do you come from?" The expected answer will be that of America, the person's state of residence, or possibly their city of origin. If this is the information that the Ukrainian speaker of English wishes to gain, the question "Where do you come from?" is the appropriate question. Ukrainian speakers of English should be aware that while in Ukrainian the question "Звідки ти/ви?" is sometimes interchanged with "Де ти живеш?" in English the corresponding phrase "Where do you come from" is never equivalent to the words "Where do you live?" (Kovalskaya \& Ritchey, 2001: 12). When asking a person where they live in English, they will respond with an answer that tells their current residence no matter if they have lived there one year or ten years. The mobility of American society allows and often requires frequent moves from place to place. Such phrases found in the English Language as "Home is where you hang your hat" and "Home is where the heart is," reflect this mobility practice.

When Ukrainians expressing themselves in English want to speak about the town or city they were born in, they are very apt to use the expression "my native town." It might seem natural to assume that since "native" means "рідний" in a phrase such as "my native language," it might be possible to use it with "town." However, native speakers tend to use a different expression in this context: "my hometown" (Puffalt \& Starko, 2003: 23).

Age. A common question during introductions for a Ukrainian speaker is that of the person's age. This question is not culturally appropriate for an American unless it is put to a child. This is especially true if you estimate a person's age to be over twenty-five years. It is further inappropriate to ask the age of a person's parents.

In Ukraine, the younger a person's parents are, the longer it is considered that the parents will support the children both emotionally and economically. This consideration is not the case in the US, and marriage will not usually occur unless the newlyweds are financially independent of their families.

In American society, there exist four different ages that make up a series in the concept of coming of age (досягнення повноліття). These are the ages of thirteen, sixteen, eighteen, and twenty-one. Each of them is important in the cultural understanding of the American concept of coming of age. The first age in the series is when a child becomes a teenager at the age of thirteen. The second occurs at the age of sixteen, when the teenager is allowed to apply for their driver's license. 
Obtaining a driver's license represents newfound independence and freedom. At sixteen, a particular party named "A Sweet Sixteen Party" is typically given for girls. It was at this age that girls were traditionally permitted to begin dating. The third age of importance is that of eighteen. At this age, in all US states, a person is considered a legal adult and will be legally responsible for all their actions. Additionally, they may register to vote, purchase cigarettes, own a gun, and males must register for selective service (the draft) with the US government in case of war. Depending on the state, at eighteen, a female may marry without a parents' permission. The age of twenty-one is the legal age for the purchase of alcohol. It will vary from state to state whether the legal age of drinking is eighteen or twenty-one (Kovalskaya \& Ritchey, 2001: 13-14).

In Ukraine, two significant events occur during the teenage years. The first of these events is obtaining a domestic passport at the age of fourteen. The second event, which appears at the age of eighteen, is the obtaining of full legal responsibility, rights, and duties such as the right to vote, to be elected to public office, to marry, and for males the obligation to serve in the military.

When dealing with ages, it should be noted that the Ukrainian word "дівчина" and the word combination "молода дівчина" are often wrongly translated into English as "a young girl". It is essential to avoid this translation because when the native speaker of English hears the word combination "a young girl', they assume the girl's age to be younger than ten years old. Therefore, the translation for "дівчина" or "молода дівчина" is that of either "a young woman" or "a young lady". When deciding which of these word combinations to use, it should be borne in mind that the term "a young lady" is that of the highest respect and commonly refers to accomplishments and character. In this way, the word "дівчина" is not a direct equivalent of "a young lady", since "дівчина" denotes only gender and age. Therefore, the translation of the word "дівчина" into English or of the word combination "a young lady" into Ukrainian should be done according to the particular context. The word combination "a young lady" is often used in the negative sense to chastise young girls who are not acting correctly.

The word combination "a young woman" would seldom be spoken to the person to whom the reference is made. It is often used in an arbitrary way to refer not to a specific person but rather as an open call for a woman of a specific age or to chastise someone with whom the person does not have a personal relationship.

Similarly, the Ukrainian word "хлопець", or the word combination “молодий хлопець" can be translated into English with the help of the word combination "a young man" and not "a young boy", which is an odd word combination in English with preference given to the lexical unit "a little boy" when the reference is made to a young male child.

The official retirement age for Social Security Benefits is sixty-two years of age (but can be delayed to sixty-five) in the United States. Individual businesses and organizations may have alternative ages. The government uses a specific formula to determine each person's benefits and rights in retirement and when they may retire. The worker may apply for early retirement or extend employment until seventy to the employer. Most employees have a separate retirement account outside of Social Security.

The Ukrainian retirement system allows women to retire at the age of sixty and for men at sixty-five. Like the US system, some categories of jobs allow for 
retirement to occur after a set number of years. It is common for early retirees to begin work under a different contract or in another field while officially obtaining benefits for retiring from their first job. The Ukrainian word "пенсіонер"/“пенсіонерка" can easily be translated into the English word "pensioner", though in the US the word "retiree" is used in preference over the word "pensioner". While in English, only the verbal phrases "to retire" or "to take early retirement" are used by those who will begin to collect Social Security (government support, which is similar to the Ukrainian concept of пенсія). In Ukrainian, the use of the word combination "йти на пенсію" (to go to pension) is standard.

Occupations/Jobs. During an introduction, if you want to know the person's occupation, the most appropriate way to do this is to ask, "What do you do for a living?" Alternatively, form the question in a way that you gain the information through the person who introduced you by asking them, "Do you and Tanner work together?" The second question allows the person to choose whether they want to reveal where they work or in what capacity they know the person who introduced you to each other. The question "What do you do?" is an acceptable way of starting a conversation, a quick way of ferreting out the individual's profession, and may indirectly provide information regarding the person's income level. Salaries and income are not proper conversation subjects (Visson, 2013: 63).

A typical Ukrainian English student's question is, "What are you?" when they wish to discover a person's occupation. The use of this phrase is unclear to a native speaker of English since this question is open-ended and could mean to seek information concerning anything from a person's nationality to their relationships with others.

In English, the word "occupation" refers to a person's vocation/profession or their principal work. In contrast, the word "job" can refer to work that is temporarily done, usually miscellaneous and typically outside of one's profession at a set pay.

Studies. One of the most confusing areas of conversation between Ukrainians and Americans is that of studies. Let us consider the following example: "On several occasions, I have used the word "student" to describe someone studying in a school, and have been very quickly corrected - "He is only a pupil" (Puffalt \& Starko, 2003: 33).

From this example, we see that while a Ukrainian will use the word "студент"/“студентка" only to refer to someone who studies at a higher educational institution, an American will use the word "student" to refer to anyone of any age who studies anywhere from pre-school to the university level. The Ukrainian term used to describe students who are high-school age or below is "учень"/“учениця". The popular translation of "учень"/“учениця" into English is often made with the help of the British word "pupil", which Americans understand but do not use. It is essential when translating the word "student" into "студент"/“студентка" or "учень"/“учениця" to give careful attention to the age and type of institution of the learner.

Similarly, an American might use the word "school" about elementary, junior high/middle, or high schools and higher learning institutions such as universities. Thus, if an adult uses a phrase such as "I am returning to school," one can safely assume that they are finishing their degree or getting a higher degree at the university level. Americans will often interchange the words "college" and "university". The only difference between the two is the number of degrees given and the number of faculties available in which to study. 


\section{Meeting and Parting Etiquette}

In the course of greeting people in English, as in many languages, it is customary to ask a question about the other person's well-being which is not really a request for information. The phrase "How are you?" functions more as a greeting than as a genuine question. "How are you?" is not an inquiry into an interlocutor's physical health (Cypres, 2001: 10). In most cases, the native speaker of English who asks "How are you?" is barely listening to the answer, as shown in the following example:

\footnotetext{
"How are you today?" - "Nice!"

The student who answered my greeting in this way was probably surprised to see by my reaction that something in his cheerful reply was startling to me. It was necessary to explain the problem to the pleasant young man! (Puffalt \& Starko, 2003: 4).
}

For Americans, there is only one standard response to "Hi, how are you?" That is "Fine, and you?" The English word "nice" conveys a totally different meaning than "fine", because it describes someone's character in general, rather than their condition at a given moment. This reply, then, implies, "I am a nice person", so it would not be used under any circumstances as a reply in an exchange of greeting (Puffalt \& Starko, 2003: 24).

Variants of "fine" include "OK," "Pretty well," "Great," "Super," "Fantastic," or "I'm not complaining." "I'm good," an expression, which has become very common, should be avoided. Despite its popularity, this expression is grammatically wrong, and can also sound perilously close to "I am a nice person". Another common meaning of "I'm good" is "I'm OK, don't need help," as in "Are you all right with that heavy suitcase?" "Thanks, I'm good" (Visson, 2013: 60).

When asking a Ukrainian “Як справи?" ("How are things?"), they often answer "Нормально". It is important to note that the Ukrainian word "нормально" does not convey the idea inherent in "normal." The closest rendering of "нормально" would be "OK, I guess," or "Not bad."

Other versions of "How are you?" include "How are things?" but never "How are your things?" which could sound like an inquiry regarding the individual's property or finances. Or the question could be, "What's up?/How's life (treating you)?/How are you doing?/What's new?" This purely conventional question does not require any detailed answer.

The answer "fine" holds even for people who are not at all "fine" - someone who has lost his/her job, whose child is ill, or whose house has just been damaged by fire. An American will generally only share with a close friend that, "Well, I've been having some problems lately," or, colloquially, that things are "not so great/hot." If the situation is really awful, he/she may say "Pretty bad/lousy." Otherwise, the answer is "fine," followed by a short explanation. For example, "Well, actually/in fact, I've been a bit under the weather with the flu, but I'm feeling better."

"I've got a bad cold" or, at worst "I've been having some health problems recently" is about as much information as most Americans will care to communicate. The kind of detailed medical bulletin many Ukrainians provide in response to such questions will not be received with great enthusiasm. For "positive- 
thinking" Americans, people with whom one wants to associate are by definition individuals who are doing "fine." It is obligatory, no matter how badly you are feeling, to display optimism publicly.

"Я погано себе почуваю" can be rendered by "I'm not feeling well" (never "I'm feeling badly"), or "I'm feeling a bit low." If things are really very bad, "Я почуваюся кепсько", the answer could be "I'm feeling rotten." If the problem is more emotional/psychological than physical, such as " $Я$ не в дусі", then "I'm in the dumps" or "I'm feeling a bit out of sorts" will do.

At the end of a conversation an American often says, "We must get together." That "must," however, contains no indication of "потрібно" or "необхідно". It is a purely empty phrase, with a meaning that runs the gamut from "I'd love to see you soon" to "I hope I never see you again." "Must" here has the same force as "You must come visit us soon" or "You really must try this piece of chocolate cake" (Visson, 2013: 65). These are all non-binding expressions of a suggestion or intention. Very close in vagueness of intent to "We must get together" is "Let's have lunch." If, however, there is a suggestion of a more specific time, the speaker indicates a sincere intention of getting together. Otherwise, the phrase is equivalent to saying "See you some time or other". Let us consider the following example:

When Monique arrived from Paris, her first reaction was that people were very friendly and open, unlike the situation in her country, where one is often more reserved when meeting someone. Over time, she became confused by the mixed signals she was getting and decided she did not understand how to interpret what people were saying and thinking. When someone said, "Let's get together sometime", this did not mean that an invitation was forthcoming. Other expressions such as "See you later" or "Talk to you soon" or "Let's have lunch" were never followed up, and she began to think people did not like her. What she learned was that people say things as part of "small talk" that do not always have the meaning they imply. "Talk to you soon" or "See you later" are just polite conversation, not to be taken literally. Many non-natives are bewildered by the fact that people say things they do not really mean and may see this as insincerity. In California, this is compounded by all the hugs and physical displays, which seem so overtly friendly, yet do not imply any follow-up contact or even an open door to pursue someone's friendship (Cypres, 2001: 214-215).

This example illustrates that standard formulas ("Let's get together sometime", "See you later", "Talk to you soon", "Let's have lunch" and the like) in language can be one of the barriers to communication that occurs between people who have different cultural backgrounds.

\section{Receiving Guests}

Is "Come over for a cup of tea" the equivalent of "Заходьте на чай"? In the US an invitation to have "a cup of coffee" or "a cup of tea" means exactly that. "Come over for a cup of tea" is in no way equivalent to the hospitality understood in the Ukrainian invitation "Заходьте на чай”. For a Ukrainian "чай” means a hot drink accompanied by a variety of cakes, cookies, and snacks, while for an American this phrase means just that - a cup of tea, with, perhaps, a few cookies or a slice of cake. 
There is no expectation that there will be any snacks, salads, or other kind of food or drink. If someone suggests "going out for coffee," that means going to a café and at most ordering a piece of pie or a cookie along with the coffee. An invitation to someone's house at an hour that does not coincide with lunch or dinner time does not by any means indicate that a meal will be served (Visson, 2013: 96-97).

In Ukraine, the amount and variety of food offered to guests is an expression and measure of generosity. Skimping on food for guests, or serving too little, is unthinkable. In the US, the notion of hospitality and the kind of food offered to the guests is highly contingent on social and cultural factors, as will be seen from the following example:

\begin{abstract}
Sophia came to the United States from Athens and settled in Michigan. She loved and appreciated the freedom that women have in American society. In one of her early contacts, she was invited to lunch by a couple from the university. She dressed nicely and was expecting a nice meal and good company. Her host and hostess greeted her wearing jeans and then served her a sandwich and potato chips. Sophia was shocked and upset, convinced that the people inviting her did not like her very much. She did not understand that, in the United States, lunch is often a simple meal, such as a sandwich or salad, and that people are pretty casual about invitations to their homes; they may not make a big fuss. They may even be invited to dinner and be served a hamburger or pizza, or they may have to serve themselves from a kitchen or dining room table. This shocks many visitors who are used to greater formality with invited guests (Cypres, 2001: 215-216).
\end{abstract}

Behavior while sharing food differs significantly from culture to culture, and certain Ukrainian and American habits are strikingly different. For example:

On a visit to the United States, a Ukrainian professor from Warsaw organized a reception for his colleagues. He served wine and hors d'oeuvres and invited the guests to sit around a table. Although all present spoke Ukrainian, one sensed a certain discomfort among the Ukrainian Americans, who were not used to sitting at a table during a cocktail party and preferred to move about from guest to guest. The host commented later that he did not understand "the choreography at American parties" (Osvita: Ukrainian Bilingual Education, 1985: 252).

The famous American institution of the cocktail party is conversationally focused. Since the cocktail party's purpose is to have people "mingle", they are supposed to talk to as many other people as possible, spending only a short period of time with each individual. It is pretty customary at a cocktail party for people to walk up to individuals they do not know and introduce themselves. Cocktail parties and buffets are particularly popular in the US. Unlike Ukrainians, Americans do not like being "stuck" at a table, sitting next to the same people all evening. Both the cocktail party and the buffet provide constant opportunities for moving around (Visson, 2013: 98-99).

In the US, people plan ahead. Americans make strict schedules, appointments, and arrangements (Fedoriachenko \& Kurovska, 1998: 3), whereas Ukrainians do not like to plan far in advance, even meetings with friends. An invitation to lunch three weeks from now is perfectly normal, for the American feels that they control time and the course of events, and not the other way round. Ukrainians tend to feel that who knows what might happen three weeks from now. Who knows what доля (fate) 
may have in store that far in the future? Anything could happen: no one can predict the course of events. Ukrainians believe that their future depends on many external factors, which are beyond their control.

For Americans, since "time is money," it is important to treat both one's own time and that of other people with great respect. Inviting someone to come over at the last minute is disrespectful because it implies that the person's time is not essential, that they have no plans of their own and can come over whenever you decide you want them around. The same holds true for dropping in without an invitation, as illustrated by the following example:

Ramon, a native of Argentina, thought people in the States are too formal and not close enough. In the first place, nobody hugged or kissed you when you greeted them, as in his country; even the distance people stood from each other seemed to indicate that they wanted to avoid closeness. He was surprised that you need to be invited by a friend to dinner rather than just show up at the friend's house because a friend can always stop by uninvited in his country. He did not understand that in the United States everything has to be organized, even dinner with friends, and that if you arrive at someone's house uninvited, it is considered impolite. Ramon concluded that people in the States have an obsession with organization and formality (Cypres, 2001: 218).

There is another point that comes up. In the above example, we can see that one's use of space conveys meaning. Space operates as a language as much as time does (Fedoriachenko \& Kurovska, 1998: 4). Proxemics is one of the most important aspects of non-verbal communication. People handle space differently-the culture largely determines the differences. Thus, North Americans and Latin Americans have fundamentally different proxemic systems. While North Americans usually remain at a distance from one another, Latin Americans stay very close to each other. Americans prefer more personal space than Ukrainians do. It is considered rude and unfriendly in Ukraine to keep a considerable distance during the conversation - while the preference in the US is for a wider reach.

\section{Conclusion}

The above-given examples underscore the point that communication is more than just vocabulary lists and grammar rules. Language and communication represent and reflect the culture and society of native speakers. Misunderstanding and misinterpretation of verbal and non-verbal messages arise when the speaker (sender) and listener (receiver) do not fully understand each other's language and culture. We can conclude that mastering a foreign language's verbal system does not guarantee effective communication. Learning the non-verbal techniques of that foreign language and its culture is also essential.

Language and culture's intimate connection derives from the fact that language is the primary vehicle for expressing cultural perspectives and participating in social practices and interactions. The inextricably woven aspects of culture are manifested in the language of those who live in the culture. The presentation of immediate life situations and the communication of subtle cultural nuances ensure that the language becomes more attractive to students. It is important to stress that 
English teachers should teach the fundamental areas of cultural understanding breakdowns at the every-day level of life between native Ukrainian and American English speakers.

\section{References}

Cypres, Linda. 2001. Let's Speak Business English! Moskva: Rolf.

Fedoriachenko, Larysa and Kurovska, Olena. 1998. Business Writing Specifics. Kyiv: Znannia.

Hall, Edward T. 1981. The Silent Language. New York: Doubleday, Anchor Books.

Knodel, Liudmyla. 2007. Anhliiska mova v praktychnomu spilkuvanni. Kyiv: Vyd. PALYVODA A.V.

Kovalskaya, Ludmila and Ritchey, Erin. 2001. Breakthroughs in Basic Breakdowns of Intercultural Communication. Maikop: Adygei State University.

Osvita: Ukrainian Bilingual Education. Ed. by Manoly R. Lupul. Edmonton: Canadian Institute of Ukrainian Studies, University of Alberta, 1985.

Puffalt, Don and Starko, Vasyl. 2003. Speak Authentic English! Lutsk: VKF "Ahrospetsservis." Znannia.

Radevych-Vynnytskyi, Yaroslav. 2006. Etyket i kultura spilkuvannia. Kyiv:

Visson, Lynn. 2013. Where Russians Go Wrong in Spoken English. Moscow: R. Valent. 